\title{
牛乳類に対するペプシンの凝固作用について \\ On the Clotting of Milks by Pepsin
}

(昭和 34 年 6 月 4 日受理)

森日出男

(Hideo Mori)

There are many reports on the relationship between the time necessary for clotting of milk in vitro by pepsin, papain, or rennin and the firmness of curd formed in vivo, and also on the fact that the longer this time is, the better the digestivility of the curdis.

The influence of various preparations or additives on the clotting time of dried skimmed milk solution by pepsin was investigated.

Following results were obtained:

1) clotting time was lengthened by a longer mixing or boiling time.

2) the addition of saliva to liquid milk lengthened the clotting time, the addition of salts, on the contrary, shortened, sugar did not show the decided results.

緒言

rennin p pepsin などは牛乳類を凝固することは古 くから知られていることであり1), その in vitro の凝固 に要する時間は in vivoに胃の中で形成される curd の tension と大きな相関があることも既に多くの研究があ る2)。

学校給食用には乾燥脱脂ミルクが古くから使用されて いるが, 液体乳に調製する際のミキサーの処理時間, 加 熱時間，砂糖または食塩の添加などについて一定のもの がないが，これらの差異は氮固時間にいかなる差を生す゚ るかをPepsinを用いて各々相対值を測定し併せて市乳 も材料として湘定し参考に供した。

\section{実験}

Pepsin：使局したPepsin は黒石製薬製、淡黄色で やや特異の朵あり，著しく吸湿性。その蛋白分解力価は Gross 法3)で 667 であつた。使用した Casein は広瀬薬 品製，Pepsin 溶液は牛乳類により大いに厓があるが大 略 5〜30 分程度で凝固がおこるよ5 $0.001 \sim 0.01 \mathrm{~g} / \mathrm{cc} の$ 溶液としその液を $0.5 \sim 1.0 \mathrm{cc}$ 使周した。

測定方法：測定温度は体温に近い点及び従来の文献な ど4により $35^{\circ} \mathrm{C}$ にた。 $100 \mathrm{cc}$ 容量のエルレンマイヤ ーフラスコに供試乳 $10 \mathrm{cc}$ をとり予め $35^{\circ} \mathrm{C}$ 以上の水温* の水槽に 30 秒間浸して振と5, 後とり出してPepsin 液 $1 \sim 0.5 \mathrm{cc}$ 注加して $35^{\circ} \mathrm{C}$ の水槽に浸し時々振とうしなが ら肉眼で明らかに凝固したと锠められるまでの時間を測 定した。
乾燥脱脂ミルク液の調製法：文部省の指導は $22 \mathrm{~g}$ を溶 解して $180 \mathrm{cc}$ にするのであるが，実際に学校では $22 \mathrm{~g} に$ 水 $180 \mathrm{cc}$ を加える場合が多い。(この際，液は全量194 $197 \mathrm{cc}$ 程度になる。）この実験においては前者の例によ り, 試料 $30.56 \mathrm{~g}$ を溶解して $250 \mathrm{cc}$ とし逆流冷却器を付 して沸滕水中に10分間清けただちに流水中で泠却して供 試した。

\section{参考実験}

(1) Pepsin 溶液の濃度及び好理温度による续固力の 差異について

市乳を材料とした場合のPepsin 液の濃度と処理温度 による凝固状態の変化は第 1 図のようであつだ。時間測 定は，2回数值が合えばその值をとり，そうでないとき は3 回行いその平均值をとつた。

(D)各種牛乳類の凝固時間

各種牛乳類を前記方法で㠜固時間を測定したが材料に より全く多種多様であつた。その例をあげると@，(Bの ごとくである

この酸度は常法により乳酸として算出。水分は100〜 $102^{\circ} \mathrm{C} 3.5 \mathrm{hrs}$ 加熱に打ける減量を以つてした。

学校給食用乾燥脱脂ミルクは殆んどその大半が輖入品

* $35^{\circ} \mathrm{C}$ 以上の水温とい5のは予熱水槽の水温であ り，そこから取り出してビニレットでPepsin液 (室昷)を0.5〜1cc 注加したとき（約8〜10秒を要 す。)試験牛乳が丁度 $35^{\circ} \mathrm{C}$ になるように予熱水槽の 温度を定める。例えば窨温 $15^{\circ} \mathrm{C}$, 水温 $12^{\circ} \mathrm{C}$ (Pepsin 液温度) 位であれば予熱水槽の水温を約 $42^{\circ} \mathrm{C}$ にし ておく。 


\section{第 1 圀}

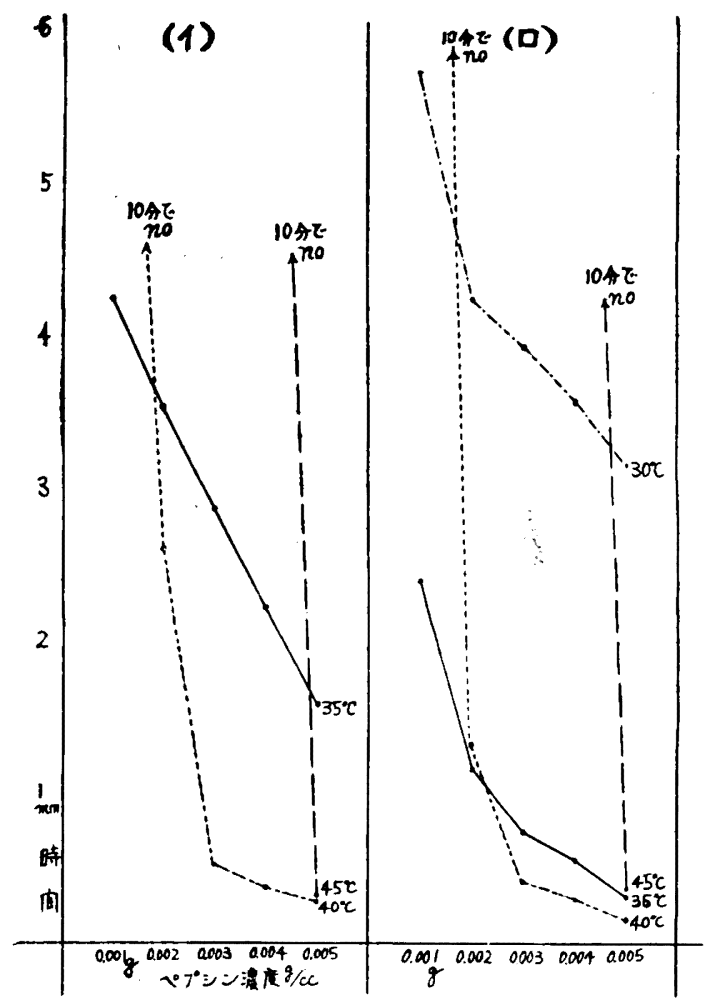

(1)は750C 15 秒処理市乳酸度 $1.92 \mathrm{cc}$

(D)は75。C 15 秒処理市乳(ホモ) " $2.21 \mathrm{cc}$

（酸度は10ccの牛乳を中和するに必要な $\mathrm{N} / 10 \mathrm{NaOH}$ のcc 数) (ベプシン液はいゔれも $1 \mathrm{cc})$

\section{(4) 市乳の例}

Pepsin 液 $0.5 \mathrm{cc}(0.01 \mathrm{~g} / \mathrm{cc})$

\begin{tabular}{|c|c|c|c|c|}
\hline $\begin{array}{l}\text { 处理 } \\
\text { 業者名 }\end{array}$ & 項 & 凝固時間 & 处理場に批ける处理方法 & 酸度 \\
\hline A & 社 & 60分でno & $62 \sim 65^{\circ} \mathrm{C} 30$ 分 & $1.82 \mathrm{cc}$ \\
\hline B & 社 & 60分でno & $75^{\circ} \mathrm{C} 15$ 秒 (加工乳) & 2.00 \\
\hline $\mathrm{C}$ & 社 & 39 分 & $75^{\circ} \mathrm{C} 15$ 分 $\left(\begin{array}{c}\text { ミネラ } \\
\text { 強化 }\end{array}\right)$ & 1.91 \\
\hline B & 社 & 18秒 & $75^{\circ} \mathrm{C} 15$ 秒 & 1.82 \\
\hline $\mathrm{C}$ & 社 & 5 分 20 秒 & $75^{\circ} \mathrm{C} 15$ 分 (Jersey) & 2.27 \\
\hline B & 社 & 35秒 & $75^{\circ} \mathrm{C} 15$ 秒 $\left(\begin{array}{ll}\text { ホモ } & ヒ と タ \\
ミ & \text { 強化 }\end{array}\right)$ & 2.10 \\
\hline $\mathrm{C}$ & 社 & 10 分 & $75^{\circ} \mathrm{C} 15$ 分 (ホモ) & 1.91 \\
\hline
\end{tabular}

であり関税定率法により衛生試験以外の理化学試験のた めに採取使用することは禁止されているのでややまとま つた数量の試料が調達できないので本実験においては主 として国産品を使用した。上記のよ5に各市乳類につい
(B) 乾燥脱脂ミルクの例

\begin{tabular}{|c|c|c|c|c|}
\hline 銘 柄 & 凝固時間 & ヘ ブシン夜 & 水分 & 酸度 \\
\hline 1 国内産 & 50 分 & $1 \mathrm{cc}(0.5 \mathrm{~g} / 100 \mathrm{cc})$ & $7.41 \%$ & $1.92 \%$ \\
\hline 2 輸入品 & 17 分 30 秒 & $0.5(0.05 / 100)$ & $4.67 \%$ & $2.32 \%$ \\
\hline 3 & 40分でno & $0.5(0.05 / 100)$ & $3.77^{\circ}$ & $2.21 \%$ \\
\hline 4 & 4 分 30 秒 & $0.5(0.05 / 100)$ & $2.93 \%$ & $1.60 \%$ \\
\hline
\end{tabular}

て数字か区今まちまちであり, 又乾燥脱脂ミルクも輸入 品はメーカーは数十種にも及ぶのであるが同一のものを 使つて比較相対値を測定することは支障はない。

(I) 食塩添加

精製塩を用い最高の濃度は $1 \mathrm{cc} に 0.2 \mathrm{~g}$ を含むように して種々の濃度のものを作り，その1ccを添加して凝固 時間を測定した。

(1) 市 乳

\begin{tabular}{|c|c|c|}
\hline 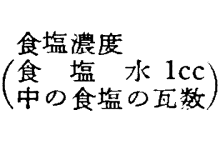 & $\begin{array}{c}\text { 第 } 1 \text { 例 } \\
\text { Pepsin 液 } 0.5 \mathrm{cc} \\
\text { 市乳7 } 75^{\circ} \mathrm{C} 15 \text { 秒处理 } \\
(0.5 \mathrm{~g} / 100 \mathrm{cc}) \\
\text { 酸度 } 1.98 \mathrm{cc}\end{array}$ & $\begin{array}{c}\text { 第 } 2 \text { 例 } \\
\text { Pepsin 液 } 0.5 \mathrm{cc} \\
\text { 市乳 } 75^{\circ} \mathrm{C} 15 \text { 秒处理 } \\
(0.1 \mathrm{~g} / 100 \mathrm{cc}) \\
\text { 酸度 } 1.92 \mathrm{cc}\end{array}$ \\
\hline 0 & $\begin{array}{l}\text { 分 秒 } \\
2.10\end{array}$ & $\begin{array}{c}\text { 分 秒 } \\
7.06\end{array}$ \\
\hline $\left.\begin{array}{ll}0 & \left(\begin{array}{l}\text { 水のみ } \\
1 \mathrm{cc}\end{array} \text { 注加 }\right.\end{array}\right)$ & 4.27 & 13.00 \\
\hline 0.02 & & 9.30 \\
\hline 0.04 & 1.25 & \\
\hline 0.05 & & 8.00 \\
\hline 0.07 & & 6.12 \\
\hline 0.1 & 2.01 & 11.10 \\
\hline 0.14 & 1.55 & \\
\hline 0.2 & 2.07 & \\
\hline
\end{tabular}

(D) 乾燥脱脂ミルク

国内産 水分 $7.41 \%$ 酸度 $1.92 \%$

食塩水は $1 \mathrm{cc}$ 添加

Pepsin 溶液は $1 \mathrm{cc}$ 注加 $(0.5 \mathrm{~g} / 100 \mathrm{cc}$ のの)

\begin{tabular}{|c|c|c|}
\hline 食塩濃度 $\left(\begin{array}{c}\text { 食 塩 水 } 1 \mathrm{cc} \\
\text { 中の食塩の瓦数 }\end{array}\right)$ & 凝 & 固 時 間 \\
\hline 0 & & 50 分 0 秒 \\
\hline 0 (水のみ $1 \mathrm{cc}$ 注加) & & 90. 0でno \\
\hline 0.04 & & 23. 30 \\
\hline 0.1 & & 2. 35 \\
\hline 0.14 & & 2. 13 \\
\hline 0.2 & & 1. 37 \\
\hline
\end{tabular}

（II）加 熱

牛乳類は加熱時間を長くすれば soft curd milkにな るといわれるか，乾燥脱脂ミルクを用いて種々の時間沸 腾水中に漫し, 後すぐに水冷して測定に供した。供試粉 
乳は (I)の (D) と同じ。

Pepsin 液 $1 \mathrm{cc}(1 \mathrm{~g} / 100 \mathrm{cc})$

\begin{tabular}{|c|c|c|c|}
\hline 加 熱 & 凝 & 固 & 間 \\
\hline 処理時間 & & 食塩水 1cc 添加 & $\left(\begin{array}{l}1 \mathrm{cc} \text { 中 } 0.2 \mathrm{~g} の \\
\text { 精製塩を合む。 }\end{array}\right)$ \\
\hline $2^{\text {分 }}$ & $37^{\text {分 }}$ & & $37^{\text {秒 }}$ \\
\hline 5 & 42 & & 38 \\
\hline 10 & 50 & & 39 \\
\hline 15 & 1 時間 22 & & 50 \\
\hline 30 & 2. 03 & & 1 分 30 \\
\hline 45 & & & 11. 10 \\
\hline 60 & & & 19. 02 \\
\hline 90 & 2. 20 & 1時間 & ค7. 00 \\
\hline
\end{tabular}

（III）ミキサー処理時間

学校給食で使用する場台, 少量の微温湯に粉乳を入れ ミキサーで覺找して濃厚乳液を作りそれを釜の熱湯中に 注入するのであるが，この夹験においては前記したよう な方法で液体液に調製した後種々の時間 mixer にかけ て凝固時間を測定した。供試粉乳は輸入品。水分 $4.67 \%$ 酸度（乳酸として） $2.32 \%$ のの。Pepsin 液は $1 \mathrm{cc}$ $(0.1 \mathrm{~g} / 100 \mathrm{cc})$ mixer は National 製品高速 13,000r.p.m。

\begin{tabular}{|c|c|c|c|}
\hline mixer 処理時間 & 凝固時間 & mixer 处理時間 & 凝固時間 \\
\hline 0 & $\begin{array}{c}\text { 分 } \text { 秒 }_{4.03} \\
\end{array}$ & 6 分 & $\begin{array}{c}\text { 分 秒 } \\
6.50\end{array}$ \\
\hline 30秒 & 4.47 & 7 & 7.25 \\
\hline 60 & 5.45 & 10 & 10.00 \\
\hline 2分 & 6.25 & 11 & 10.01 \\
\hline 4 & 6.40 & 12 & 10.01 \\
\hline 5 & 6.45 & & \\
\hline
\end{tabular}

\begin{tabular}{|c|c|c|c|}
\hline \multirow{2}{*}{$\begin{array}{l}\text { 砂 糖 濃 度 } \\
\left(\begin{array}{l}\text { 添加した砂 } \\
\text { 糖の瓦数 }\end{array}\right)\end{array}$} & 凝 & 固 & 間 \\
\hline & 第 1 例 & 第 2 例 & 第 3 例 \\
\hline 0 & $\begin{array}{l}\text { 分 秒 } \\
7.06\end{array}$ & 分 秒 & $\begin{array}{l}\text { 分 秒 } \\
2.30\end{array}$ \\
\hline $0 \quad\left(\begin{array}{l}\text { 水のみ } \\
\text { 添加 }\end{array}\right)$ & 14.54 & 5.19 & 3.35 \\
\hline 0.03 & 21.30 & & \\
\hline 0.06 & & & 4.02 \\
\hline 0.075 & 17.25 & & \\
\hline 0.105 & 17.25 & & \\
\hline 0.12 & & & 3.30 \\
\hline 0.15 & 14.50 & & \\
\hline 0.18 & & & 3.45 \\
\hline 0.24 & & & 3.38 \\
\hline 0.3 & & 5.21 & \\
\hline 0.35 & & & 3.30 \\
\hline 0.6 & & 5.40 & \\
\hline
\end{tabular}

(IV) 砂糖添加

(1) 牛孚類に砂糖溶液を添加しその㠜固時間の差異を 湘定した。精製糖を用い最高濃度は $1 \mathrm{cc} に 0.6 \mathrm{~g}$ の砂楉 を含さ液を作つた。

Pepsin 液は $1 \mathrm{cc}(0.5 \mathrm{~g} / 100 \mathrm{cc})$ 砂糖液は(第 1 例)(第 2 例) は $1 \mathrm{cc}$ (第 3 例) は $0.5 \mathrm{cc}$ を添加。供試市乳は何 れも $75^{\circ} \mathrm{C} 15$ 秒処理。酸度は各々 $1.92 \mathrm{cc}, 1.98 \mathrm{cc}, 1.93 \mathrm{cc}$ であつた。

(口) 乾懆脱脂ミルク液を作り砂楉を溶液とせず固形砂 糖を添加した例を示す。供試粉乳は輸入品。水分 $4.67 \%$ 酸度(乳酸として) $2.32 \%$ Pepsin 液 $0.5 \mathrm{cc}(0.05 \mathrm{~g} / 100 \mathrm{cc}$ )

\begin{tabular}{c|l||c|l}
\hline 添加砂糖量瓦 & 凝固時間 & 添加砂糖量瓦 & 凝固時間 \\
\hline 0 & 17分30秒 & 1.2 & 36 分06秒 \\
0.3 & 20.02 & 2.4 & 48.40 \\
0.6 & 26.31 & & \\
\hline
\end{tabular}

\section{(V) 唾液添加}

牛乳類を飲用するときは一息に飲まずゆつくり味わつ て飲むのがよいといわれるが，唾液が混合することは凝 固時間にどんな変化を示すかを調査した。

\begin{tabular}{|c|c|c|c|c|c|}
\hline \multirow[t]{2}{*}{ 水 } & \multirow[t]{2}{*}{ 唾液 } & \multicolumn{4}{|c|}{ 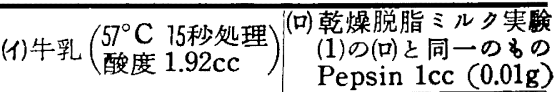 } \\
\hline & & $\begin{array}{c}\text { Pepsin 1cc } \\
(0.01 \mathrm{~g})\end{array}$ & $\begin{array}{c}\text { Pepsin 1cc } \\
(0.0025 \mathrm{~g})\end{array}$ & $\begin{array}{l}\text { 食塩水 1cc } \\
(0.3 \mathrm{~g}) \text { 添加 }\end{array}$ & $\begin{array}{l}\text { 食塩水 } 1 \mathrm{cc} \\
(0.06 \mathrm{~g}) \text { 添加 }\end{array}$ \\
\hline $0^{\text {滴 }}$ & $0^{\text {滴 }}$ & $15^{\text {秒 }}$ & $\begin{array}{l}\text { 分 秒 } \\
3\end{array}$ & $58^{\text {秒 }}$ & 分秒 \\
\hline 20 & 0 & 23 & 3.10 & 66 & 12.25 \\
\hline 15 & 5 & 37 & 3.10 & 66 & 10.10 \\
\hline 10 & 10 & 38 & 3.30 & 68 & 10.45 \\
\hline 5 & 15 & 37 & 3.55 & 73 & 9.20 \\
\hline 0 & 20 & 38 & 3.35 & 77 & 9.23 \\
\hline
\end{tabular}

\section{考察及び要約}

凝固時間の長い牛乳が胃の中で soft curd を作り消 化吸収がいといわれているが，学校給食において使用 する乾燥脱脂ミルクを液体乳に調製する際の mixer 㚾 理, 加熱好理時間, 砂糖, 食塩, 唾液添加などにより Pepsin による乲固時間にいかなる差異を生じるかを実 测した。

予備実験として市乳を材料として種々の濃度のPepsin 溶液と処理温度による凝固力の差異について夷測しその 結果を第 1 図に示したか，

(1)一定温度において Pepsin 濃度と凝固時間とは必ず しも直線関係を示さなかつた。

(只処理温度, Pepsin 濃度及び凝固時間の間には法則姓 が見いだされない。温度が高いときは，低温では凝固が 起り得る低いPepsin 泱度において凝固が起り難いか及 
は起らないとい5現象がある。Pepsin の蛋白分解力と 㮢固力の温度による競合とい5点は将来檢討したい。 各種市販牛乳を材料として凝固時間を調查したが各処 理場により硕る大きな差がある。乾燥脱脂ミルクと市乳 では前者の方が凝固時間が長いがこれは加熱, 乾懆とい 万製造過程が原因であり5)性質が異なるので比較対比す ることは妥当でないか，市販乳においてもこのように差 が甚しく単に酸度による差のみが原因とは考えられな い。従つて処理場の異なる牛乳を凝固時間のみを以つて 消化吸収の良否を断定することは未だ検討の余地がある と思われる。

契験（Ｉ）において食塩添加による变異を調查したが この場合は殆んど例外なく凝固時間が短缩された。但し 荟度の增加と時間の短縮は比例的な関係でなく，ある特 定の濃度に拈いては，それょり低い食塩濃度の際よりも 却つて凝固時間が長くなるという点があつた。食㙁添加 の場合の凝固の状態は他の場合と明らかに異なりきれい なPaste 状になる。

実験 (II) において加熱による变化を央測した。徉来 より加熱は $\mathrm{Ca}$ イオンの減少を来して soft curd にな ることが知られているがこの笑験においても明らかに凝 固時間が増加することが想められる。90分加熱した場合 乳液がやや茶色に着色した卖例があつた。

mixer 処理については実験（III）で取り上げたがよく $\operatorname{mix}$ するとい5ことは凝固時間を長くする。この実験 においては約10分間の mixer 処理で最大値に達する。 元来, 乾燥脱脂ミルクは液体乳に調製する方法によつて は不安定なものであり，例えば，液体乳に調製する際， 沸滕水に浸漬する時間を $2 \sim 3$ 分間位で止めれば，調製 值後の乳液の凝固時間と30分以上放置したものとは相当 に凝固時間が異なる。後者の方が凝固時間が遅い。肉眼
では鑑別できない「真の溶湤」と「夙溶液」との差であ ろちと思われる。

実娩（IV）において砂糖添加の影響を尖測した。従来 より砂糖は soft curd にする効力があるといわれるが, 本央験においては，乾燥脱脂ミルクの場合に非実用的に 多量の砂糖を添玑して凝固時間が長くなつた事例をあげ たが，市乳の場合は不定である。引用した事例以外にも

「どちらともいえ彷」といら場合の実駼例が 3 例，凝固 時間が長くなつた事例が 2 例，逆の事例が 1 例あつた。

実験 (V) は唾液添加の効果を調べた。牛乳類はよく 口の中で啮んで飲めといわれ睡液中の Mucine が消化 吸収を助外るといわれるが，本年駼においては顕著な延 長は認められなかつた。萑を添加してから実測にかか る汔の時間については将来梚討してみたい。

終りにPepsin 剤を贈与下さつた黒石製薬鳴宮治三氏 実騃室を提供され種々便宜を計つて下さつた西宮市所在 兵庫栄養学園に樑く感謝の意を表す。

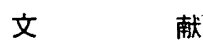

1) 例えば

N. J. Berridge: Advances in Enzymology.

15. 423 . (1954)

2) Rowland. S. J. \& Soulides. D.:

J. Dairy Res. 13. 85. (1942)

Mattick. E. C. V. \& Hallet, H. S. :

J. Agr. Sci. 19. 425. (1929)

3）津郷友吉：レンネットの製造に関する研究 (佐々木, 前野編: 畜産物の科学 I II 合併号 162 (1951)

4) 津鄉友吉 : ibid 佐々木, 津郷, 最明：栄養と食糧 11. 196 (1958)

5) 佐々木, 津郷：乳の化学 (1958)

（兵庫県教育委員会体育保健課）

栄焲失調幼児の尿中クレアチニン排泄量

K. L. Standard, V. G. Wills, J. C. Waterlow $A m$. J. Clin. Nutr. 7. 271 (1959).

尿中へのクレアチンニン排泄量は筋肉の量に比例する といわれるか，栄䖭失調で体重が標準よりはるかに少な い患肾を病院に収容して，体重の回復，クレアチニンの 排泄量を測定すると，2 2 ケの間に後者はほとんど二倍 に増加し，前者の增加度を上回る結果を得た。このこと
から，入院時における筋肉の消耗度は，体重の減少度よ りもはげしいものであつたことが考学られる。

入院当初にクレアチニンの排泄量が激变することがし ばしば経験されたが，浮腫がとれる時期に排泄量が增す 傾向があつた。しかし变動の原因をよく説明することの できないヶースもあつた。

（小＼cjkstart池） 